\title{
Socio-Economic Development of Russia at the Contemporary Stage
}

\author{
Lydia A. Korshunova ${ }^{\mathrm{a} *}$, Natalia G. Kuzmina ${ }^{\mathrm{b}}$, Anna I. Litovchenko ${ }^{\mathrm{c}}$, Fidan G. \\ Babayeva $^{\mathrm{d}}$ \\ * Corresponding author: Lydia A. Korshunova, korshunova@tpu.ru
}

${ }^{a}$ Tomsk polytechnic university, 634050 Lenina str., 30, Tomsk, Russia, korshunova@tpu.ru,+7-961-892-38-77

${ }^{b}$ Tomsk polytechnic university, 634050 Lenina str., 30, Tomsk, Russia,kuzminang@tpu.ru,

${ }^{c}$ Tomsk state university, 634050 Lenina str., 36, Tomsk, Russia, politeco@ef.tsu.ru

${ }^{d}$ Tomsk polytechnic university,634050Lenina str.,30,Tomsk, Russia,kamil_gunel@mail.ru

\begin{abstract}
http://dx.doi.org/10.15405/epsbs.2017.01.50

The paper considers summary indicators of socio-economic development of Russia and its position in the world in the period of 1990-2014 in accordance with the concept of worldwide human development. The indexes characterizing the demographics and income, life expectancy, power consumption and quality of life are presented. The dynamics of incomes in Russia is presented in the light of poverty and hunger elimination. A comparative analysis of the quality of life in Russia and the countries with the largest economies in the world (USA, China, Japan, Germany) is conducted. It is shown that in its socio-economic development of Russia is greatly inferior to such highly developed countries like the US, Japan, Germany. During the considered period of time (24 years) Russia has failed to achieve significant social and economic growth. More than 16 million people live below the poverty line. More than half of the population have per capita income below the national average. In difficult domestic and international conditions, Russia fulfilled its commitments to reduce poverty level and Russian government puts every effort to sustain the achieved position in the socio-economic life of the population.
\end{abstract}

C 2017 Published by Future Academy www.FutureAcademy.org.uk

Keywords: Gross domestic product; human development index; a living wage; the minimum wage; life expectancy; the average years of schooling.

\section{Introduction}

Socio-economic development of Russia at present is complex and contradictory. This is due to the following reasons: 
- The process of formation of the market and market structures is still in progress. Corruption and crime hinder the development of the legal markets;

- Economic sanctions by the leading countries caused shortages of basic commodities, which led to higher prices and inflation. Economic restructuring, aimed at import substitution and development of entrepreneurship is carried out urgently;

- There is an outflow of financial and intellectual capital, and ongoing transformation and rehabilitation of infrastructure of Crimea require additional investment;

- The fall in world oil prices have reduced government revenues, a significant portion of which is generated through the export of hydrocarbons;

- Complicated relationship with Ukraine and Turkey, the fight against international terrorism and assistance to Syria have led to increased development of the military-industrial complex by reallocating budget funds.

All of the above mentioned factors affect the internal development of the country and the quality of social life.

Classical economic theory has pointed out the role of the human in the transformation of social production. Adam Smith and his followers believed the person is not only a source but also an important part of social wealth. However, throughout the twentieth century was dominated by the traditional concept of growth. It was assumed that the increase in aggregate output will increase the nation's wealth and reduce poverty. The industrial boom in the twentieth century based on market and competition, predatory use of natural resources have led to the environmental crisis, which gradually turns into an ecological catastrophe (destruction of the ozone screen, dehydration of continents, the disappearance of many species of animals and plants, etc.). To prevent an environmental catastrophe special committee at the United Nations developed in 1993 and adopted in 1997 the Rio Declaration on Environmental Development. All UN member states committed themselves to the sustainable development of economy, energy and society. In accordance with this Declaration the Organization for Economic Cooperation and Development (OECD) at United Nations has formulated the concept of human development, which was adopted by 192 countries in 2001. This concept is based on the fact that the development of social life cannot be seen only as the growth of material goods and services. Its aim is to create conditions for the people, conducive to long, healthy and creative lives. The true wealth of any country is its people. In addition to economic indicators it is necessary to assess the role of education, science, health, etc. This approach promotes growth of economic efficiency of activities (Sen, 1999; Mahbub ul Haq, 1995).

The concept of human development abides by 4 principles:

1. Productivity. Everyone should be able to work productively for a decent monetary reward.

2. Equality. All people originally should have equal opportunities regardless of race, ethnic and gender differences.

3. Sustainability. Access to opportunities must be provided for both present and future generations. To do this, material, human and environmental capital should be renewable. 
4. Empowerment. People should participate in all the processes that shape their lives (longevity, education, rights and freedoms, income, consumption, gender equality, the environment, security, etc.).

\section{Indicators of socio-economic development of Russia}

Basic principles of the new social society began in Russia after 1917. This process took place in a complex socio-economic situation both domestically and internationally (civil war and intervention of 1917-1920, World War 2 of 1941-1945, Cold War in subsequent years). By 1990, the country has achieved certain results. USSR acted on the world stage as a powerful country with a developed social structure. But there have been many difficulties and problems that led to the transformation of public property into private.

After the collapse of the USSR economic reforms aimed at speeding up the transition to a market economy, have led to a demographic crisis and the destruction of the pension system, health, education, social security and social protection. Prior to 2005-2006 social transformations in Russian society were not a priority. In 2006, the President of the Russian Federation has formulated a large-scale program of social and demographic development. National programs like "Health", "Education", "Affordable Housing" started to be implemented. The government has realized that economic growth is not possible without focus on social development. Since 2000 sharp decline in all indicators of socio-economic development has stopped, and in 2005 began their rise. This is evidenced by the data presented in Table 1 (Russian Federation Federal State Statistic Service, 2016; Enerdata. Energy Statistical Yearbook 2015, 2016; Central Intelligence Agency, 2016; Human Development Reports: United Nations Development Programme, 2016).

The main indicator of the quality of life is the growth and longevity of its population, which are dependent on incomes.

Table 1. General indicators of socio-economic development of Russia.

\begin{tabular}{|c|c|c|c|c|c|c|c|c|}
\hline Indicators & 1990 & 1995 & 2000 & 2005 & 2010 & 2012 & 2014 & $\begin{array}{l}\text { Relationship of } \\
2014 \text { to } 1990, \%\end{array}$ \\
\hline Population, millions & 147.6 & 148.4 & 146.8 & 143.5 & 142.8 & 143 & 143.3 & 97 \\
\hline Birth-rates, per 1000 people & 13.4 & 9.3 & 8.7 & 10.2 & 12.5 & 13.3 & 13.3 & 99 \\
\hline Death-rates, per 1000 & 11.2 & 15 & 15.4 & 16.1 & 14.2 & 13.3 & 13.1 & 116 \\
\hline Longevity, years & 69.1 & 64.5 & 65.3 & 65.3 & 68.9 & 70.0 & 70.1 & 101 \\
\hline GDP, trillions of dollars & 1.19 & 0.83 & 1.00 & 2.13 & 2.93 & 3.45 & 3.47 & 315 \\
\hline Energy consumptions, billions of $\mathrm{kWh}$ & 914 & 679 & 693 & 760 & 851 & 875 & 873 & 95.5 \\
\hline $\begin{array}{l}\text { GDP per capita, thousands of } \\
\text { dollars/person }\end{array}$ & 8.06 & 5.59 & 6.81 & 14.84 & 20.5 & 24.1 & 24.9 & 308 \\
\hline $\begin{array}{l}\text { Electricity consumption per capita, } \\
\text { thousands of } \mathrm{kWh} / \text { person. }\end{array}$ & 6.19 & 4.57 & 4.72 & 5.29 & 5.96 & 6.11 & 6.09 & 99 \\
\hline Human Development Index (HDI) & 0.729 & - & 0.717 & - & 0.773 & 0.777 & 0.798 & 109 \\
\hline
\end{tabular}

Economic growth (GDP) and the comfort of living of the population are uniquely determined by the amount of electrical energy consumed. During the considered period of time in Russia the demographic crisis is observed. The natural decline in the population was first overcome in 2012. However, the excess of births over deaths in 2014 was observed only in several regions of Russia (republics with a 
low share of the Russian population, Tyumen region and Moscow). Low fertility is associated with low incomes, lack of proper housing, poor working conditions, low levels of reproductive health and others. However, the demographic problem is largely determined not by material wealth, but ideological and spiritual state of society. This is proven by results of fertility in the national republics, especially in the North Caucasus, where the population has lowest incomes.

Since 2005, all the indicators of socioeconomic development improved. Birth rate increases, mortality rate decreases, GDP per capita and energy consumption, as well as life expectancy are growing.

As summary characteristics of the quality of life human development index (HDI) is used. It is based on life expectancy at birth (years), average school life expectancy (years) and per capita GDP in parity of consumption capacity (US. Dollars). The Human Development Index has also increased, although it differs significantly by region. For example, in Moscow, it is 0.964 (higher than the world's highest rate) due to the high indices of income and education.

The person should have sufficient funds for the realization of their basic needs. One of the main Millennium Development Goals is the eradication of absolute poverty and hunger. Russia has committed itself in 2015 to reduce poverty by 2 times and eliminate extreme poverty. At the regional level as the poverty indicators the following indicators are used:

- Population with per capita incomes below the poverty line; poverty line is determined by each country in accordance with its capabilities;

- Deficit of income - the value of incomes of the population below the poverty line;

- Income share of the poorest groups of the population;

- Income differentiation factor - the ratio of the average income of the richest population to the poorest;

- $\quad$ Ratio of per capita income to living wage.

Table 2 shows the average indices, characterizing money incomes of the Russian population (Russian Federation Federal State Statistic Service, 2016). The data show that during the period considered incomes are growing, but the minimum wage (SMIC) is 1.4 times lower than the living wage $(\mathrm{LW})$.

Table 2. Incomes in Russia.

\begin{tabular}{|c|c|c|c|c|c|c|}
\hline Indicators & 2005 & 2010 & 2012 & 2013 & 2014 & $\begin{array}{l}\text { Relationship of } \\
2014 \text { to } 2005, \%\end{array}$ \\
\hline Average monthly salary, thousands of rubles/person & 8.55 & 20.95 & 26.6 & 29.79 & 32.49 & 308 \\
\hline Minimum monthly wage, thousands of rubles/person & 0.80 & 4.33 & 4.61 & 5.2 & 5.55 & 690 \\
\hline Living wage (LW), thousands of rubles/month & 3.018 & 5.688 & 6.510 & 7.306 & 8.050 & 266 \\
\hline The proportion of people with incomes below the LW, \% & 17.7 & 12.6 & 10.7 & 10.8 & 11.2 & 63 \\
\hline Deficit of income, $\%$ & 5 & 2.1 & 1.2 & 1.2 & 0.9 & 18 \\
\hline Income differentiation factor, times & 15.2 & 16.5 & 16.4 & 16.3 & 16.0 & 105 \\
\hline $\begin{array}{l}\text { The share of income of } 20 \% \text { of the population with the } \\
\text { lowest income in the total money income, } \%\end{array}$ & 6 & 5.4 & 5.2 & 5.2 & 5.2 & 86 \\
\hline The ratio of per capita income and the LW, \% & 268 & 333.3 & 356.7 & 354.9 & 344.8 & 128 \\
\hline
\end{tabular}

$*$ in 2014,1 US dollar $=38,42$ rubles. 
The number of people with incomes below the living wage decreased in 2014 compared to 2005 by 1.5 times; deficit of income to the poverty line decreased by 5 times; the ratio of per capita income and the living wage increased by 1.28 times; the living wage has increased by 2.6 times, and the minimum wage - by almost 7 times; monthly wage increased by 3.8 times. But still $11 \%$ of the population (over 16 million people) are below the poverty line. Over $50 \%$ of the population have incomes below the national average.

High income differentiation factor and a low share of income of the poor in the total income indicate a high differentiation of the population by income. The rich get richer and the poor get poorer. Russia is a country with a large number of subjects, differing in terms of economic and social development. Of the 84 regions in Russia, only 23 regions have a share of the poor below national average. The most disadvantaged are the Southern and Siberian Federal District with 18 regions total, from which only 1 has a share of the poor below the national average. In those regions where the ratio of per capita income and a living wage is above the national average, income differentiation factor is higher and the share of the poor is lower. For example, in regions of the value of income differentiation factor ranges from 10 to 20, while in Moscow it is 28 . If the ratio of regional per capita income and a living wage varies from $180 \%$ to $450 \%$, in Moscow it is $600 \%$. The share of income of the poor in regions ranges from $4.5 \%$ to $6.7 \%$, while in Moscow it is equal to $3.7 \%$.

Severe income inequality leads to the stratification of the population, which can lead to social instability. Stabilization of incomes of the population with the lowest incomes and a reduction income differentiation factor indicates that differentiation processes are slowing down.

\section{Russia's place in the world community}

Since the 192 countries signed the Millennium Declaration of the United Nations of the Human Development, it is interesting to evaluate the place of Russia in the world community. Table 3 shows all the main general indicators of socio-economic development of the United States, China, Japan, Germany (countries with the largest economies in the world) and Russia in 2014 and the change in these indicators compared with 1990 (Enerdata. Energy Statistical Yearbook 2015, 2016; Central Intelligence Agency, 2016; Human Development Reports: United Nations Development Programme, 2016).

Table 3. General indicators of socio-economic development of various countries.

\begin{tabular}{|c|c|c|c|c|c|}
\hline Indicators & USA & China & Japan & Germany & Russia \\
\hline Annual GDP per capita, thousand dollars/person & 54.4 & 13.25 & 37.49 & 46.33 & 24.9 \\
\hline The ratio of per capita GDP in 2014 to $1990, \%$ & 235 & 1086 & 110 & 211 & 380 \\
\hline Annual per capita consumption of electricity, thousands of $\mathrm{KWh} /$ person & 12.01 & 3.54 & 7.10 & 6.38 & 6.09 \\
\hline The ratio of per capita electricity consumption in 2014 to $1990, \%$ & 98 & 643 & 102 & 98 & 102 \\
\hline Average life expectancy, years & 79.1 & 75.8 & 83.5 & 80.9 & 70.1 \\
\hline Increased life expectancy in 2014 compared to 1990 , years & 3.1 & 5.8 & 3.5 & 4.9 & 1.0 \\
\hline The average duration of education, years & 12.9 & 7.5 & 11.5 & 13.1 & 12.0 \\
\hline The increase in duration of education in 2014 compared to 1990 , years & 0.6 & 2.6 & 1.6 & 5.1 & 2.8 \\
\hline The Human Development Index (HDI) & 0.915 & 0.727 & 0.891 & 0.916 & 0.798 \\
\hline The ratio of HDI in 2014 compared to $1990, \%$ & 106.6 & 144 & 109 & 117 & 109.4 \\
\hline
\end{tabular}


The data show that in 24 years all countries except China and Japan, increased GDP per capita by 2-3 times; Japan - only 1.1 times, while China - 10.8 times. Consumption of electric power in China has increased 6.43 times, while in other countries it remained almost unchanged. In Russia, compared to US GDP per capita and electricity consumption is 2 times lower. In China, per capita GDP is 4 times lower than in the United States, and the consumption of electric power - 3.4 times lower.

The Human Development Index (HDI) as a general indicator of quality of life, in all countries except China for the period considered increased by 7-17\%; China - by $44 \%$. In highly developed countries the HDI of about 0.9; China - 0.727; Russia - 0.798. The world's average HDI is 0.702. The highest HDI in the world is in Norway (0.944) with a per capita GDP - 98.86 thousand dollars / person.

Highest life expectancy is in Japan, the lowest is in Russia. Compared to 1990, it increased by 3-5 years in all countries but Russia, where it is only 1 year. Lifespan in Russia is 9 years lower than that in the United States and 14 years lower than that in Japan. The duration of education in China is 4-5 years less than in other countries, in which it lasts about the same period of time.

\section{Conclusion}

Russia is on a new stage of historical development. The ongoing process of re-evaluation of national values and reconciling the interests of the individual, society and state. National security has allowed the country to re-evaluate the role and place of Russia in the world.

In its socio-economic development of Russia is greatly inferior to such highly developed countries like the US, Japan, Germany. During the considered period of time (24 years) Russia has failed to achieve significant social and economic growth. Many sectors of the economy are working on a worn out equipment, using outdated technology, which is reflected in the growth of labor productivity, the quantity and quality of goods and its energy intensity. This also affects the level of incomes of the population.

Russia is one of the richest countries on the reserves and production of natural resources, but their use is not enriching the Russian society but only individuals. Russian society has become stratified. More than 16 million people live below the poverty line. More than half of the population have per capita income below the national average. The share of income of $20 \%$ of the population with the lowest income is $5.2 \%$ of total national income.

Internal and external factors influence the implementation of social programs in Russia, causing their underfunding. Russia fulfilled its commitments to reduce poverty level. The proportion of people with incomes below the poverty line decreased compared to 2005 by 1.58 times, and compared to 2000-2.5 times.

The decrease of income differentiation factor, as well as stabilization of the poverty indicators suggests slowing differentiation processes and some improvement in the situation in the country. In difficult domestic and international conditions, Russian government puts every effort to sustain the achieved position in the socio-economic life of the population. 


\section{References}

Central Intelligence Agency (2016). Retrieved from https://www.cia.gov/library/publications/the-worldfactbook/rankorder/2102rank.html

Central Intelligence Agency (2016). Retrieved from https://www.cia.gov/library/publications/the-worldfactbook/fields/2001.html

Enerdata. Energy Statistical Yearbook 2015 (2016). Retrieved from https://yearbook.enerdata.net/worldelectricity-production-map-graph-and-data.html

Human Development Reports: United Nations Development Programme (2016). Retrieved from http://hdr.undp.org/en/composite/trends

Mahbub ul Haq (1995). Reflections on Human Development. Oxford: Oxford University Press.

Russian Federation Federal State Statistic Service (2016). Retrieved from http://www.gks.ru/bgd/regl/b15_12.

Sen, A. (1999). Development as Freedom. Oxford: Oxford University Press. 